\title{
Over reliance on pesticides and poor handling practices characterize intensive vegetable farming: case of selected smallholders in southwestern Uganda
}

\section{Eziron Rwakipamba}

Uganda Martyrs University Faculty of Agriculture

Godfrey Sseremba ( $\sim$ gsseremba16@gmail.com )

Uganda Martyrs University Faculty of Agriculture https://orcid.org/0000-0001-9625-0570 John Byalebeka

Uganda Martyrs University Faculty of Agriculture Joseph Ssekandi

Uganda Martyrs University Faculty of Agriculture Julius Mwine

Uganda Martyrs University Faculty of Agriculture

\section{Research article}

Keywords: Chemical spray frequency, intensive vegetable production, pesticide spillages, produce intoxication

Posted Date: March 10th, 2020

DOI: https://doi.org/10.21203/rs.3.rs-16579/v1

License: (c) (i) This work is licensed under a Creative Commons Attribution 4.0 International License.

Read Full License 


\section{Abstract}

This study investigated the extent of pesticide use and poor handling practices which characterize intensive vegetable farming, among smallholder vegetable farmers in south western Uganda. $100 \%$ of respondents were using pesticides for control of pest and diseases, and over $78 \%$ applied pesticides on a twice-a-week basis. Majority of farmers used pesticides in violation of recommended procedures/rules; use of unsafe storage facilities, ignore risks and safety instructions, and did not calibrate the spray equipment, and disposed of containers unsafely. Poor pesticide-handling practices were associated with farmers' lack of knowledge and awareness in use and handling, inadequate extension services, low education levels, and the everyday context in which pesticides were bought and used. A careful approach to analyze pesticide use and handling practices to systematically identify ways to change the current farmers' practices needs to be adopted or undertaken.

\section{Background}

Pesticides usage is gaining increased attention in the media for their beneficial effects in fighting pests and diseases. Pesticide use is now a commonly used practice by most farmers to control pests and diseases in their vegetable production systems. This is often at the expense of the environment and human health; the widespread use of pesticides has caused a growing concern about their effects on the ecosystem components. Poor pesticide handling practices have been recognized as a major threat to the ecosystem and biodiversity sustainability as well as a public health problem (resulting in increased cases of non-communicable diseases where new research results indicate that pesticides increase the risk of severe health problems like cancer, Parkinson, dementia, diabetes and other diseases, Eyhorn et al., 2015). However, there is still a lack of attention paid to the significant role that poor pesticide handling practices play in contributing to the problem. In many countries, water and food contamination by pesticides is considered an important method of human harm. While there are no accurate data available on acute pesticide poisoning due to occupational and accidental exposure, most estimates are in the range of several million cases per year, as this is in line with (Lah 2011; Hicks 2013; Mahmood et al., 2016). Acute pesticide poisoning is a serious problem in developing countries and emerging economies, where many farmers use highly hazardous products, often without adequate protective measures, using application practices that may lead to water, food/produce and environmental pollution (Eyhorn et al., 2015).

Although pesticides enter the human body through ingestion, inhalation or penetration via skin; majority of people get affected via intake of pesticide contaminated food and water (Mahmood et al., 2016). Multiple pesticide residues are found in drinking water/surface water and food; unintentional pesticide poisoning and acute effects are also a serious problem in agricultural communities, of the low and middle-income countries (Jørs et al., 2018). It is critical therefore, to effectively investigate pesticide handling practices in respect to levels of farmers' awareness in pesticide handling and application practices. Most studies about pesticides in Uganda have reported less on pesticide use and handling practices in respect to farmer's knowledge. Excessive use of pesticides may lead to the destruction of 
biodiversity (Mahmood et al., 2016). Inappropriate use of pesticides leads to reduction of beneficial species such as bees, birds, soil and aquatic organisms. Applying pesticides on fields can affect animals and other living organisms which interact with the targeted pests. The reduction in these other organisms can result in changes in the biodiversity of an area and affect natural biological balances (Amuoh, 2011).

Pesticides can affect other areas during application and can cause severe problems in different crops, livestock, waterways and the general environment; wildlife and fish are the most affected. Taking special note of weather conditions can reduce drift. The use of pesticides may lead to residues in human food and drinking water. This can either be by direct application onto the food, or by biomagnification along the food line and run off in domestic water. Not all levels are undesirable but unnecessary and dangerous levels must be avoided through knowledge of the dynamics of safe pesticide use and good agricultural practice. When the same pesticides are overused, the targeted pest can develop resistance to the pesticide. Excessive exposure to pesticides without safe handling procedures and wearing of protective clothing can lead to poisoning. Poisoning risks depend on dose, toxicity, duration of exposure accumulation levels and sensitivity. Farmers and farmworkers can get exposed to pesticides through four primary routes namely ingestion, inhalation, dermal absorption, and absorption through the eyes.

Individuals in a farm situation can get exposed to pesticides in various ways (Okello and Swinton, 2010; Amuoh, 2011). Exposures to toxic pesticides can result in health hazards in the form of acute or chronic illnesses (Maumbe and Swinton, 2003; Amuoh, 2011). It is critical therefore to be aware about the extent of use and handling practices of pesticides among smallholder farmers who dominate the majority in sub-Saharan African countries. This study intended at investigating the extent of pesticide use and poor handling practices in intensive vegetable farming areas by smallholder farmers.

\section{Methods}

\section{Study area}

A case study was made in major vegetable producing areas of Kabarole district, in western Uganda. The major cultivated vegetable crops in the area include tomatoes, cabbages, onions, egg plants and green pepper. Before starting the study, ethical approval was sought from Office of the Dean, Faculty of Agriculture, Uganda Martyrs University.

\section{Study design and population}

A cross-sectional case study was conducted. The target population was the vegetable farmers involved in production of major vegetables (such as tomatoes, cabbages and onions). The number of farmers involved in vegetable production (Tomatoes, Cabbages, and Onions, among others) in the different villages of the 3 parishes of Kichwamba was not directly known and the study sample was established based a guide by Syed (2017) as detailed herein. Consultation of local council (LC1) chairpersons with 
the aid of the respective parish chiefs in conjunction with the sub county agricultural officer was also made in order to access vegetable producers with farming experience of not less than one year.

\section{Sampling}

Sample size was determined according to Syed (2017) who asserted that, if the population is unknown, a minimum of 384 responses are sufficient for substantial data collection and analysis. The standard required sample size would be around 383 for a population with a $5 \%$ margin of error and a $95 \%$ confidence level.

Using the formula for the representative sample- $\mathrm{n}$ :

$$
\begin{aligned}
& n=(Z-s c o r e)^{2 *} p^{*}(1-p) /(\text { margin of error })^{2} \\
& =(1.96)^{2 *} 0.5 *(1-0.5) /(0.05)^{2} \\
& =3.8416 * 0.25 / 0.0025 \\
& =384.16
\end{aligned}
$$

Note: $(Z$-score $=1.96$ for a $95 \%$ confidence level $)$

Then the standard sample computed above would then be adjusted to the specific research population using the following formula below;

$\mathrm{n}$-adjusted $=(\mathrm{n}) / 1+[(\mathrm{n}-1) / \mathrm{N}$ - population $]$

But our study population is 300 vegetable farmers, our margin of error $=7 \%$, $p$ - value $=0.5$ and a confidence interval of $90 \%$ (1.645) was used for this research. Therefore, the sample size was determined as below;

$$
\begin{aligned}
& n=(Z \text {-score })^{2 *} p^{*}(1-p) /(\text { margin of error })^{2} \\
& =(1.645)^{2} * 0.5 *(1-0.5) /(0.07)^{2}
\end{aligned}
$$


$=138$

NB (Z-score is 1.645 for a $90 \%$ confidence level)

Therefore: sample $n$ above was adjusted to the current research population $(\mathrm{N}=300)$

$\mathrm{n}$ adjusted. $=(\mathrm{n}) / 1+[(\mathrm{n}-1) / \mathrm{N}-$ population $]$

$$
\begin{aligned}
& =(138) / 1+[(138-1) / 300] \\
& =(138) / 1+(137 / 300) \\
& =(138) /(1+0.457) \\
& =(138) / 1.457 \\
& =138 / 1.457 \\
& =94.715 \\
& =95 \text { Respondents }
\end{aligned}
$$

The study was to be conducted on 95 respondents as per sample calculations above, however due to limited time, resource constraints; terrain of the area and other logistical issues, the study was able to involve 90 respondents.

In his study snowball sampling technique was employed. One vegetable farmer who was introduced to the research team by the Local Council chairperson was interviewed, who then led the interviewer to the next farmer and the process continued until the sample population, above was covered. The number of respondents achieved per parish depended on population of vegetable farmers in that parish (Table 1).

Table 1: showing number of respondents achieved per parish 


\begin{tabular}{cll} 
S/N & Parishes & number of respondents \\
\hline 1. & Bwanika & 46 \\
\hline 1. & Mabale & 38 \\
1. & Kihondo & 06 \\
\hline Total & & 90
\end{tabular}

\section{Data collection}

The variables considered included age, gender, marital status and level of education, number of farmers using pesticides on vegetables, Frequency of application and Application interval at a period of weather conditions. Data was collected through a farmer's survey by face-to-face interviews with farmers, field observations and pictures taken as well. One interviewed farmer led the interviewer to another farmer until data was collected from all sampled farmers. A structured questionnaire (questionnaire developed and used for this study is included as supplementary material) was made and administered to collect the data on the extent of pesticide use by farmers and farmer's' awareness in the use and handling of pesticides. Observations in farmers' fields were done and where possible pictures portraying relevant information were taken.

\section{Statistical analysis}

The data was then statistically analyzed while considering the following statistical variables; number of farmers using pesticides in their vegetable fields, frequency of application, and application interval at particular period of weather conditions. Descriptive statistics using percentages; of farmers using pesticides, farmers who apply pesticides to same crop a specific number of times in a given time period and farmers who apply pesticides in a particular time interval in respect to particular weather condition respectively, were used.

\section{Farmers' awareness in the use and handling of pesticides}

\section{Data collection}

Data was collected through a farmer's survey by face-to-face interviews with farmers, field observations and pictures taken as well. A first interviewed farmer led the interviewer to another farmer until data was 
collected from total sample of farmers. A structured questionnaire was made and administered to collect the data on farmers' awareness in the use and handling of pesticides. Observations in farmers' fields were done and where possible pictures portraying relevant information were taken. Data on the following variables was collected: trainings in pesticide use and handling, extension services, education level, calibration of the spray equipment, method/skill of application, disposal method, and method of pesticides storage and consultation for advice.

\section{Statistical analysis}

Descriptive statistics using percentages of farmers; who have received training in pesticide use and handling, farmers who received pesticide extension services, farmers of different education levels, farmers who are able to calibrate their spray equipment, farmers using a particular way of applying pesticides i.e. spot vs. routine application, farmers using a particular disposal method, farmers using a particular way of pesticides storage and farmers who consult on pesticide knowledge e.g. from other farmers respectively, were used. Inferential statistics were not appropriate since nonprobability sampling was used. Quantitative data was analyzed using frequency tables, and graphs. Analysis of qualitative data was by content familiarization involving reading through the interviews several times after collecting responses, which enabled the researcher to make notes and understand the data very well. This helped the researcher to locate bits of information that supported the interpretation and elaboration where the researcher explored the details of the data in order to obtain in-depth understanding of the research phenomenon. The margin of error of $7 \%$, p-value of 0.5 and a confidence interval of $90 \%$ (1.645) was used for this research.

\section{Results}

\section{Social demographic information}

Basic information about the socio-economic characteristics farmers is presented in Table 2. Information about the social demographic background was obtained from both male and female individuals who use pesticides. The socio-demographic characteristics included sex, age, marital status, and level of education. A total of 90 farmers were contacted during the study (participation rate $=100 \%$ ). Majority of the study participants were between the age brackets of 15-30 (47.8\%), ages 31-40 (37.7\%), 41-50 (10\%), and $4.5 \%$ were aged 51 and above. Most of these farmers were males $(74.4 \%)$ whereas $28.9 \%$ were females. $80 \%$, of the participants were married, $15.6 \%$ were single, the divorced and widowed were $3.3 \%$ and $1.1 \%$ respectively. $56.7 \%$ of participants were primary leavers, $27.8 \% \mathrm{O}^{\prime}$ Level dropouts and $6.6 \% \mathrm{had}$ high levels of education. Their average farm size was small, estimated between $0.5-1.5$ acres. Family size was about four persons per household, and average vegetable farming experience was 6 years. The high yield was the main motive behind using pesticides, followed by high profit. 
Table 2: The Socio-Demographic Data Aspects $n=(90)$

\begin{tabular}{|c|c|c|c|}
\hline Variable & Response & Frequency & Percent \\
\hline \multirow[t]{4}{*}{ AGE } & $15-30$ & 43 & 47.8 \\
\hline & $31-40$ & 34 & 37.7 \\
\hline & $41-50$ & 9 & 10 \\
\hline & 51 Above & 4 & 4.5 \\
\hline \multirow[t]{3}{*}{ RESPONDENT'S SEX } & Male & 64 & 71.1 \\
\hline & Female & 26 & 28.9 \\
\hline & Total & 90 & 100 \\
\hline \multirow[t]{7}{*}{ MARITAL STATUS } & Single & 14 & 15.6 \\
\hline & Married & 72 & 80 \\
\hline & Divorced & 3 & 3.3 \\
\hline & Widowed & 1 & 1.1 \\
\hline & Total & 90 & 100 \\
\hline & & 8 & 8.9 \\
\hline & None & & \\
\hline \multirow[t]{5}{*}{ EDUCATION LEVEL } & Primary & 51 & 56.7 \\
\hline & Lower secondary & 25 & 27.8 \\
\hline & Higher secondary & 3 & 3.3 \\
\hline & Tertiary & 3 & 3.3 \\
\hline & Total & 90 & 100 \\
\hline
\end{tabular}

Establishing the extent of pesticide use in the area

In this study, majority of farmers had grown vegetables such as onions, tomatoes, cabbages eggplants and green pepper for a long time ranging from eight months to ten years. $93.3 \%$ for more than one year, while only $6.7 \%$ for a maximum of ten months. $100 \%$ of farmers reported a pest and disease problem 
affecting their crops seasonally, monthly; weekly and daily. More than $90 \%$ of the farmers confirmed presence of pests and or diseases by themselves, whereas only $4.4 \%$ by consulting other people. $95.6 \%$ of farmers try to manage pests and disease problem by themselves and $100 \%$ of farmers reported spraying pesticides to manage pests and diseases. More than $80 \%$ of farmers rely only on pesticide spraying for management and control of pests and diseases and less than $7 \%$ of the farmers use weed control and other options of pest and diseases control in addition to chemical spraying.

Table 3: Number and percentage of farmers using pesticides (extent of pesticide use, table 1 of 4) 
Variable

Period taken by farmer in vegetable growing

How often do you face pests and or disease problem
How do you confirm type of a particular pest or disease on a veg. crop

Who determines the control method/ technique for pest or disease

How often do you apply pesticides on your farm

Pests and diseases managed by farmer

Farmer manages pests and diseases by chemical spraying

Farmer manages pests and diseases by weed control in addition to chemical control
Response

Years

Months

Total

Seasonally

Monthly

Weekly

Daily

Total

Consultation

Self-

observation

\section{Frequency Percent}

93.3

6.7

100

65.6

16.7

15.6

2.2

100

4.4

86

95.6

Total

90

100

95.6

\begin{tabular}{l} 
Self \\
Consulting \\
\hline Total
\end{tabular}

86

4.4

90

100

Seasonally $\quad 15$

16.7

Monthly 5

5.6

Weekly

70

77.8

Total

90

100

Yes 90

No

00

0

100

Total 90

Yes 90

No

00

Total

90

90

100

$90 \quad 100$

00

000

100

Yes 6

No

No

84

6.7

Total

90

93.3

100

Yes

6

6.7

Farmer uses other options of pest and disease mgt 


\begin{tabular}{lll} 
No & 84 & 93.3 \\
\hline Total & 90 & 100 \\
\hline
\end{tabular}

Farmers use more than one type of pesticides on the same crop or field and most times mixed in one tank (table 4). Findings show that $71.1 \%$ of the farmers used herbicides to prepare their fields and only $28.9 \%$ used tillage methods. $100 \%$ of farmers used conventional insecticides and fungicides for control of insect pests and fungal diseases respectively. Onions farmers used herbicides most for field preparation followed by tomato farmers, the least users being green pepper and eggplant farmers respectively. $71.1 \%$ of all farmers used conventional insecticides to control insect pests; only $28.9 \%$ did not use insecticides. $88.9 \%$ of all farmers were onion farmers who used insecticides; where as $11.1 \%$ did not grow onions. Only $38.9 \%$ of all farmers were cabbage producers and all (100\%) used insecticides; $61.1 \%$ did not grow cabbages; $70 \%$ of all farmers were tomatoes produces and all (100\%) used insecticides; $30 \%$ did not grow tomatoes.

Table 4: How farmers use different types of pesticides (extent of pesticide use, Table 2 of 4) 
Farmer uses different types of pesticides on the farm

Yes

No

Total

Farmer uses herbicides in vegetable farm

Farmer uses herbicides in Onion fields

Farmer uses herbicides in Cabbage fields

Farmer uses herbicides in tomato fields

Farmer uses herbicides in Eggplant fields

Farmer's purpose to use herbicides
Farmer uses herbicides in Green pepper fields

\begin{tabular}{ll} 
Yes \\
No \\
\hline Total
\end{tabular}

Total

\begin{tabular}{|c|c|c|c|}
\hline & No & 64 & 71.1 \\
\hline & Total & 90 & 100 \\
\hline \multirow[t]{3}{*}{ Farmer uses herbicides in tomato fields } & Yes & 42 & 46.7 \\
\hline & No & 48 & 53.3 \\
\hline & Total & 90 & 100 \\
\hline \multirow[t]{3}{*}{ Farmer uses herbicides in Eggplant fields } & Yes & 1 & 1.1 \\
\hline & No & 89 & 98.9 \\
\hline & Total & 90 & 100 \\
\hline \multirow[t]{3}{*}{ Farmer uses herbicides in Green pepper fields } & Yes & 4 & 4.4 \\
\hline & No & 86 & 95.6 \\
\hline & Total & 90 & 100 \\
\hline \multirow[t]{3}{*}{ Farmer's purpose to use herbicides } & $\begin{array}{l}\text { Kill weeds for seed bed } \\
\text { preparation }\end{array}$ & 65 & 72.2 \\
\hline & Weeding the crop & 25 & 27.8 \\
\hline & Total & 90 & 100 \\
\hline \multirow{3}{*}{$\begin{array}{l}\text { Farmer uses conventional insecticides in veg. } \\
\text { fields }\end{array}$} & Yes & 90 & 100 \\
\hline & No & 0 & 0 \\
\hline & Total & 90 & 100 \\
\hline \multirow[t]{2}{*}{ Farmer uses conventional insecticides in Onion } & Yes & 80 & 88.9 \\
\hline & $12 / 36$ & & \\
\hline
\end{tabular}


fields

\begin{tabular}{lll} 
No & 10 & 11.1 \\
\hline Total & 90 & 100 \\
\hline Yes & 35 & 38.9 \\
\hline No & 55 & 61.1 \\
\hline Total & 90 & 100 \\
\hline Yes & 63 & 70 \\
\hline No & 27 & 30 \\
\hline Total & 90 & 100
\end{tabular}

Farmer uses Conventional insecticides in Tomato fields

Farmer uses Conventional insecticides in cabbage fields

\begin{tabular}{|c|c|c|c|}
\hline & No & 55 & 61.1 \\
\hline & Total & 90 & 100 \\
\hline \multirow{3}{*}{$\begin{array}{l}\text { Farmer uses Conventional insecticides in } \\
\text { Tomato fields }\end{array}$} & Yes & 63 & 70 \\
\hline & No & 27 & 30 \\
\hline & Total & 90 & 100 \\
\hline
\end{tabular}

Findings in table 5 indicate $4.4 \%$ and $7.8 \%$ farmers were producing eggplants and green pepper respectively, and all (100\%) applied insecticides to their fields; $95.6 \%$ and $92.2 \%$ did not growing eggplants and green pepper respectively. $100 \%$ of farmers use fungicides; $88.9 \%$ of all were onion farmers and all used conventional fungicides, $11.1 \%$ farmers did not grow onions. $36.7 \%$ were growing cabbages and all (100\%) used fungicides in their fields, and 63.3\% farmers did not grow cabbage use

Table 5: How farmers use different types of pesticides (extent of pesticide use, Table 3 of 4) 
Variable

Farmer uses Conventional insecticides in Eggplant fields
Response

Yes

No

Total

Yes

Green pepper fields

Farmer's Purpose to use conventional insecticides

No

Total

Kill insect pests damaging the crop
Reduce pests

Total

Farmer use Organic insecticides in veg.

fields

Farmer uses Organic insecticides in Onion
fields

Farmer uses Organic insecticides in cabbage fields

Yes

No

Total

Yes

\section{Frequency Percent}

4.4

95.6

100

7.8

92.2

83

100

$90 \quad 100$

90

100

0

100

$90 \quad 100$

\begin{tabular}{lll} 
Yes & 0 & 0 \\
\hline No & 90 & 100 \\
\hline Total & 90 & 100
\end{tabular}

0

0

0

90

100

90

100

0

0

No

90

100

Total

90

100

Farmer uses Organic insecticides in Tomato fields

\begin{tabular}{ll} 
Yes & 0 \\
\hline No & \\
\hline Total & 9000
\end{tabular}

Farmer uses Organic insecticides in Eggplant fields

Farmer uses Organic insecticides in Green pepper fields

Farmer's purpose to use Organic insecticides

\begin{tabular}{ll} 
Yes & 0 \\
\hline No & 90 \\
\hline Total & 90
\end{tabular}

\begin{tabular}{ll} 
Yes & 0 \\
\hline No & 90 \\
\hline Total & 90
\end{tabular}

Kill insect pests and add

0

90

$90 \quad 100$

0

100

0

90

100

90

100

0

0

90

100

90

100

Page 14/36 


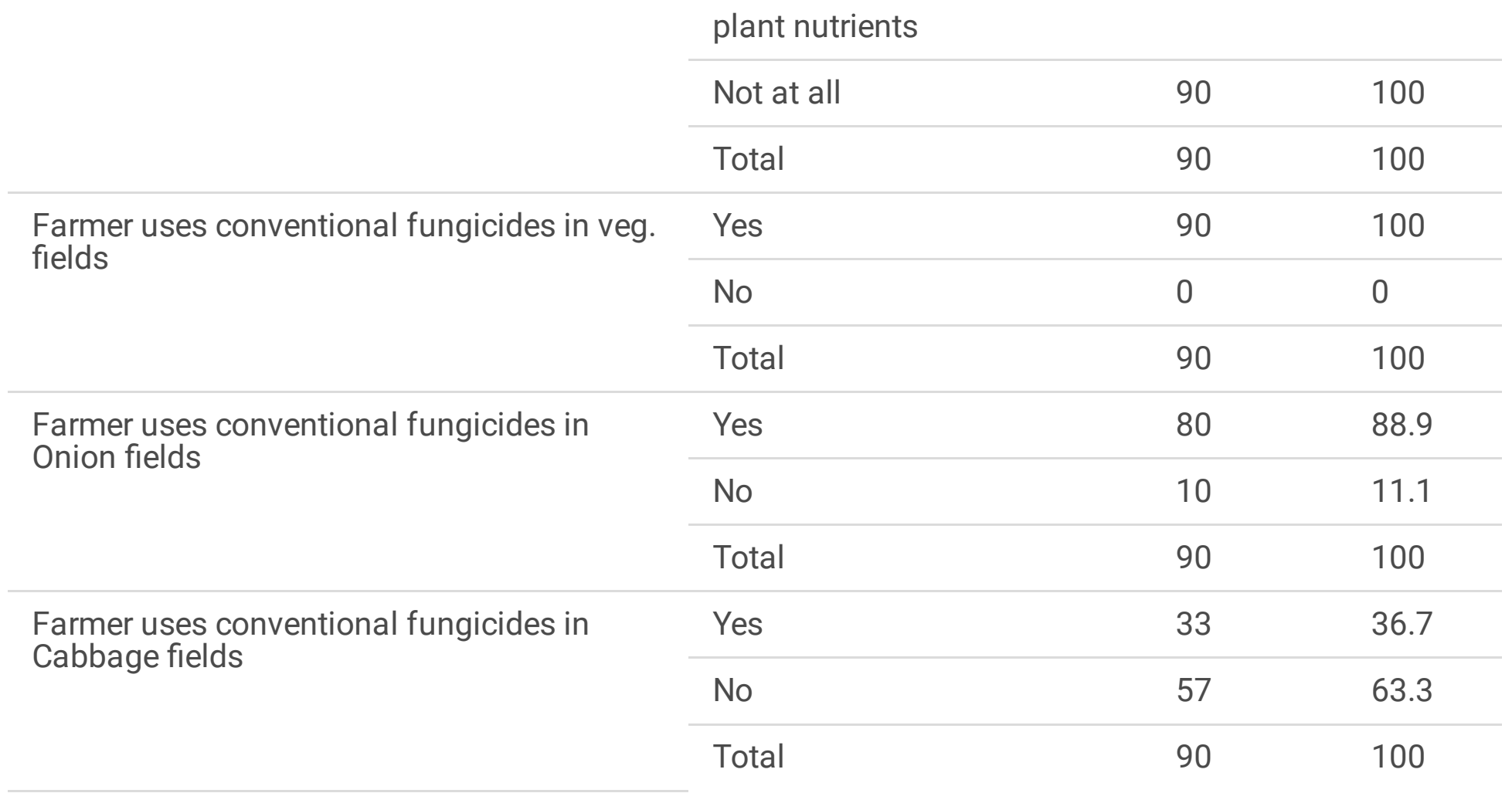

Findings in Table 6 shows that $68.9 \%$ of farmers were tomato producers and all (100\%) using conventional fungicides in their tomato fields; $31.1 \%$ of farmers did not grow tomatoes. $4.4 \%$ and $7.8 \%$ of farmers were producing eggplants and green pepper respectively and all (100\%) use conventional fungicides in their fields; $95.6 \%$ and $92.2 \%$ were not growing eggplants and green pepper respectively. No organic pesticide was used by any farmer

Table 6: How farmers use different types of pesticides (extent of pesticide use, Table 4 of 4) 
Variable

Farmer uses conventional fungicides in Tomato fields

\section{Response}

Yes

No

Total

Farmer uses conventional fungicides in Eggplant fields

Frequency Percent

62

68.9

31.1

100

4.4

Yes

No

86

95.6

Total

90

100

Farmer uses conventional fungicides in Green pepper fields

Farmer's purpose to use Conventional fungicides

Yes

No

7

7.8

83

92.2

Total

90

100

Control fungal diseases on $\quad 88$

97.8 crops

Control disease and keep 2 env't safe

Total

90

100

Farmer uses Organic fungicides in veg. fields

Yes
No
Total

Farmer use Organic fungicides in Onion fields

Yes

0

90

100

90

100

No
Total

Farmer use Organic fungicides in Tomato fields

\begin{tabular}{lll} 
Yes & 0 & 0 \\
\hline No & 90 & 100 \\
\hline Total & 90 & 100 \\
Yes & 0 & 0 \\
\hline No & 90 & 100 \\
\hline Total & 90 & 100 \\
Yes & 0 & 0 \\
\hline No & 90 & 100 \\
\hline Total & 90 & 100
\end{tabular}

Farmer use Organic fungicides in Cabbage fields

Farmer use Organic fungicides in Eggplant fields 


\begin{tabular}{llll}
$\begin{array}{l}\text { Farmer use Organic fungicides in Green } \\
\text { pepper fields }\end{array}$ & Yes & 0 & 0 \\
\cline { 2 - 4 } & No & 90 & 100 \\
\cline { 2 - 4 } Farmer's purpose to use Organic fungicides & Total & 90 & 100 \\
& Not at all & 90 & 100 \\
\cline { 2 - 4 } & $\begin{array}{l}\text { Control disease \& keep } \\
\text { env't safe }\end{array}$ & 0 & 0 \\
\cline { 2 - 4 } & Total & 90 & 100 \\
\hline Farmer uses other pesticide option types & Yes & 0 & 0 \\
\cline { 2 - 4 } & No & 90 & 100 \\
\cline { 2 - 4 } & Total & 90 & 100
\end{tabular}

Table 7 presents the level and extent of pesticide use in terms of frequency and interval of application by farmers in the study area. From the findings, $77.8 \%$ of farmers applied pesticides weekly, $5.6 \%$ and $16.7 \%$ apply pesticides monthly and seasonally respectively. $98.9 \%$ of famers apply pesticides on crops routinely with or without pests and or diseases on crops; and only $1.1 \%$ use spot spraying only when they see pests and or diseases on crops. In the terms of different weather conditions, the frequency, intensity and interval of pesticide application keep changing. During rain seasons, $47.8 \%$ of farmers apply pesticides every 4 days; $28.9 \%$ apply pesticides weekly; $15.6 \%$ apply pesticides every 5 days; $5.6 \%$ apply pesticides every 3 days and only $2.2 \%$ apply pesticides above 7 days. In dry seasons $55.6 \%$ apply pesticides in an interval above 7 days; $43.3 \%$ apply pesticides weekly and only $1.1 \%$ apply pesticides every 4 days.

Table 7: Frequency of Pesticide application and application interval in particular weather conditions 
Variable

How long have you been applying pesticides on your farm
Response

Years

Months

Total

By which method do you apply pesticides on your crop land

Routine application How often do you apply pesticides on the same crop
during rainy season

application
Frequency Percent

94.4

5.6

100

98.9

1.1

Spot 1

Total 90

\begin{tabular}{lll}
\hline every 3 days & 5 & 5.6 \\
\hline every 4 days & 43 & 47.8 \\
\hline every 5 days & 14 & 15.6 \\
\hline every 7 days & 26 & 28.9 \\
\hline Above 7 days & 2 & 2.2 \\
\hline Total & 90 & 100 \\
\hline
\end{tabular}

How often do you apply pesticides on the same crop during dry season

\begin{tabular}{lll} 
every 4 days & 1 & 1.1 \\
\hline every 7 days & 39 & 43.3 \\
\hline Above 7 days & 50 & 55.6 \\
\hline Total & 90 & 100
\end{tabular}

\section{Information concerning farmer's awareness in the use and handling of pesticides}

The level of farmer's awareness in the use and handling of pesticides (Table 8) in the study area, indicate that; $91.1 \%$ of farmers apply pesticides on crops on a routine basis irrespective of the presence or absence of pest and or diseases; $8.9 \%$ applied pesticides when pests or diseases appear on the crops. Only $27.8 \%$ consult experts for knowledge on how to apply pesticides; $72.2 \%$ do not seek for any knowledge but rely on local experiences. $97.8 \%$ of farmers decide on their own to spray pesticides in their crop's fields; $2.2 \%$ consult agriculture extension workers or neighbors regarding use of pesticides. Only $7.8 \%$ of farmers contacted received trainings in pesticide mixing and application knowledge; $92.2 \%$ do not receive any knowledge. Also $100 \%$ of the farmers mix pesticides themselves for application in their fields, irrespective of having been trained or not. Regarding mixing rates, $34.4 \%$ of farmers mixed pesticides by guessing; $60 \%$ by reading instructions on labels and $5.5 \%$ consult others (chemical dealers, extension workers, Neighbors and fellow farmers). 
Table 8: Farmer's awareness in the use and handling of pesticides (1 of 3) 
Do you consult any expert on how to apply pesticides

Yes

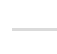

No

No

25

27.8

Total

65

90

Is Use of pesticides the only way/option to control pests and diseases

Yes
No
Total

Do you use other pests control options other than pesticides

\begin{tabular}{ccc} 
Yes & 10 & 11.1 \\
\hline No & 80 & 88.9 \\
\hline Total & 90 & 100
\end{tabular}

When do you always apply pesticides on your crops

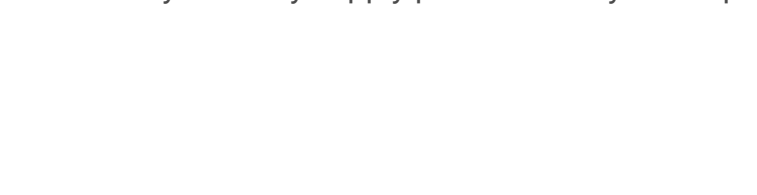

Do you consult any expert on how to apply pesticides

Who decides when and how to spray in regard to safe
use of pesticides

Have you ever received any training or knowledge about mixing pesticides

Routinely (seen or not seen the pests \& or
diseases on the crop)
diseases on the crop)

$\begin{array}{lll}\text { Spot application (when insects or disease are } & 8 & 8.9\end{array}$
seen on the crop)

$\begin{array}{lll}\text { Total } & 90 & 100\end{array}$

25

27.8

\begin{tabular}{lcc}
\hline No & 65 & 72.2 \\
\hline Total & 90 & 100 \\
\hline
\end{tabular}

\begin{tabular}{lcc} 
Self & 88 & 97.8 \\
\hline Agric. extension & 1 & 1.1 \\
\hline Neighbours & 1 & 1.1 \\
\hline Total & 90 & 100
\end{tabular}

Yes

7

83

92.2

No

Total

90 100

Do you mix pesticides for application in your field
Yes

Page 20/36 


\begin{tabular}{lcc}
\hline No & 0 & 0 \\
\hline Total & 90 & 100 \\
\hline Guessing & 31 & 34.4 \\
\hline Reading instructions on the label & 54 & 60 \\
\hline Consulting & 4 & 4.4 \\
\hline Others (guessing) & 1 & 1.1 \\
\hline Total & 90 & 100
\end{tabular}

How do you determine mixing rates

$70 \%$ of farmers interviewed (Table 9), determine the right pesticide application method by reading instructions on labels; $23.3 \%$ consult neighbors, $3.3 \%$ consult agro- dealers while $3.3 \%$ use guessing. For pesticide application frequency, $90 \%$ respondents use given sets of routine application frequencies (like twice a week, weekly, etc) with or with no pest or diseases appearing on crops; and $10 \%$ only determined application frequency by looking at presence or abundance of pests or diseases. $83.3 \%$ of farmers mix pesticides in their fields; $13.3 \%$ mixed pesticides at water sources and $3.3 \%$ mixed pesticides at their homes before application in the field. Mixing pesticides and applying them in the fields is done $100 \%$ by farmers themselves. Only $5.6 \%$ of farmers contacted accessed extension services and all the $94.4 \%$ never accessed extension services.

$84.4 \%$ (Table 9) bathe and clean spray equipments at home, $14.4 \%$ at water sources and $1.1 \%$ do it in the field, in the bush among others. $8.9 \%$ of the farmers contacted dispose pesticide containers by burying them, $28.9 \%$ by burning them, $2.2 \%$ by throwing them in water, $56.7 \%$ by throwing them in the bush and $3.3 \%$ by other means such as using them for home use or selling them. Only $1.1 \%$ of famers calibrate spray equipment; all the $98.9 \%$ of the farmers do not calibrating their spray equipment.

Table 9: Farmer's awareness in the use and handling of pesticides (2 of 3) 
How do you know the correct pesticide application method
Self, by reading instructions on the labels

\begin{tabular}{lll}
\hline Consulting the agro dealers & 3 & 3.3 \\
\hline Consulting neighbors & 21 & 23.3 \\
\hline Others (guessing) & 3 & 3.3 \\
\hline Total & 90 & 100 \\
\hline
\end{tabular}

How do you determine frequency of pesticide application

Presence and abundance of 9 pests and or disease

63 70 3.3 23.3 3.3 10
Routine with or no pest or disease present

Total

At home

At a water point or source

In the field

Total

Who sprays pesticides on your vegetable field

Where do you mix pesticides before spraying

Self

Special applicator

Total

Yes

5

\begin{abstract}
Have you ever received pesticide extension
services
Have you ever received pesticide extension
services
\end{abstract}

Where do you bath, wash your clothes, and clean the equipments after spraying
How do you dispose of used containers of pesticides 81 90 100

100

90

100

0

0

90

100

5.6

No

85

94.4

Total

90

100

At home

76

84.4

At a water source

13

14.4

Else where

1

1.1

Total

90

100

Bury them

8

8.9

Burn them

26

28.9

Throw them in water

2

2.2

Throw then a way in the bush

51

56.7

Throw them else where

3

3.3 


\begin{tabular}{llll}
\cline { 2 - 4 } & Total & 90 & 100 \\
\hline Where do you get pesticide equipment & Own & 40 & 44.4 \\
\cline { 2 - 4 } & Hiring & 49 & 54.4 \\
\cline { 2 - 4 } & Other e.g. group equipment & 1 & 1.1 \\
\cline { 2 - 4 } & Total & 90 & 100 \\
\hline $\begin{array}{l}\text { Do you calibrate your spray equipment before } \\
\text { spraying }\end{array}$ & Yes & 1 & 1.1 \\
\cline { 2 - 4 } & No & 89 & 98.9 \\
\cline { 2 - 4 } & Total & 90 & 100
\end{tabular}

More than $95 \%$ of farmers determined application rates by guessing. $66.7 \%$ of farmers were able to know the expiry dates of the chemicals by reading the label, while $33.3 \%$ could not tell the expiry dates on labels. Only $5.6 \%$ of farmers had attended seminars and workshops regarding pesticide use; $94.4 \%$ did not. Although farmers used a lot of pesticides in their vegetable fields, (table 10), $75.6 \%$ of the farmers reported being aware that pesticides through runoffs could easily reach domestic water sources; only $24.4 \%$ were not aware. $83.3 \%$ of farmers had their fields located on hills; $16.7 \%$, their vegetable fields were located in valleys where water sources were found. $100 \%$ of farmers reported all domestic water sources were located in valleys.

Table 10: Farmer's awareness in the use and handling of pesticides (3 of 3) 
None

89

98.9

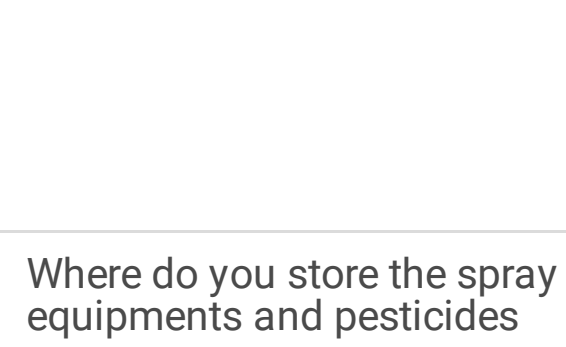

Consult

1

1.1

agric.

extension

equipments and pesticides

Total

90

100

Separate

2

store

\begin{abstract}
Do you have any knowledge about expiry dates of pesticides
\end{abstract}

\begin{tabular}{l} 
In the house \\
$\begin{array}{l}\text { Anywhere (in } \\
\text { the field) }\end{array}$ \\
\hline Total
\end{tabular}

\begin{tabular}{|c|c|c|c|}
\hline & & & \\
\hline & Total & 90 & 100 \\
\hline \multirow{3}{*}{$\begin{array}{l}\text { Do you have any knowledge about } \\
\text { expiry dates of pesticides }\end{array}$} & Yes & 60 & 66.7 \\
\hline & No & 30 & 33.3 \\
\hline & Total & 90 & 100 \\
\hline \multirow{3}{*}{$\begin{array}{l}\text { Have you attended seminars, } \\
\text { Workshops, or Trainings on safe use of } \\
\text { pesticides }\end{array}$} & Yes & 5 & 5.6 \\
\hline & No & 85 & 94.4 \\
\hline & Total & 90 & 100 \\
\hline \multirow{3}{*}{$\begin{array}{l}\text { Are you aware pesticides in farms can } \\
\text { reach water sources through runoffs }\end{array}$} & Yes & 68 & 75.6 \\
\hline & No & 22 & 24.4 \\
\hline & Total & 90 & 100 \\
\hline \multirow[t]{3}{*}{ Where is your vegetable field located } & On the hill & 75 & 83.3 \\
\hline & In the valley & 15 & 16.7 \\
\hline & Total & 90 & 100 \\
\hline \multirow{3}{*}{$\begin{array}{l}\text { Where are your domestic water sources } \\
\text { located }\end{array}$} & In valleys & 90 & 100 \\
\hline & On hills & 0 & 000 \\
\hline & Total & 90 & 100 \\
\hline \multirow{3}{*}{$\begin{array}{l}\text { Do you know some of the domestic } \\
\text { water sources and where they are } \\
\text { located }\end{array}$} & Yes & 90 & 100 \\
\hline & No & 0 & 000 \\
\hline & Total & 90 & 100 \\
\hline Have you ever seen runoffs from & Yes & 89 & 98.9 \\
\hline
\end{tabular}


No

Total
1

90
1.1

100

\section{Discussion}

Results in Table 2 imply that respondents were able to give reasonable answers in regard to the issues asked under the survey, given categories of their education levels. A wide range of vegetables produced in the area of study focus indicated the level of diversity of vegetable crop production. The high average number of years of vegetable production indicated that farmers had vast knowledge and experience in vegetable farming. High yields motivated farmers for pesticides use, followed by high profit, implying that pesticides reduced risks of crop damage by insects and fungal diseases, the major threat to crop yield, quality and profit; therefore, farmers had a sound reason to use pesticides.

In this study, $100 \%$ of farmers visited, faced a problem of pests and diseases in their fields and used pesticides to control them, implying that prevalence of pests and diseases was the driving force for farmers into pesticides use (Tables 3, 4, 5 and 6). Since majority of the farmers managed pests and disease problems by themselves imply that they used knowledge within their means, given that most of them did not receive trainings. Since more than $80 \%$ of farmers relied only on pesticide spraying for management and control of pests and diseases and only less than $7 \%$ of them used other options in addition to pesticides spraying, imply that the rate of pesticide use in the study area of focus is so high; clearly reported by $100 \%$ of farmers who produce the different vegetable crops. This reveals that the overall levels of pesticide use in the area is so significant and the implication is that it could result in the residues accumulating in water sources and food chains, exceeding safe limits and causing overall ecosystem degradation.

High reliance by farmers on chemical spraying as the major option for pest and diseases control, and use of numerous types of pesticides in their fields (Table 4), most times combined in one tank mix indicates there is a high rate and extent of pesticide use in the area; which puts a serious risk to the surrounding forms of biodiversity and entire ecosystem components, such as water resources by residual accumulation and pollution. Notwithstanding the risk of pest and disease resistance to pesticides, likely to result into more pesticides sprays due to continuous pest and disease reoccurrence which puts more risks of pesticide pollution to the environment and spillover effects through water movement, spray drifts and attachment to soil particles.

This study revealed that all farmers who were engaged in producing any vegetable crop did so with use of pesticides (insecticides, fungicides and herbicides) and in each case the usage rate was almost $100 \%$. The implication of this high rate of pesticide use therefore, is the high risk of pesticide residues accumulation of in water, air, soil particles and in the food chain, and high resistance of pests and diseases to pesticides which results into high prevalence of pests and diseases, resulting from mutant 
strains, causing changes and loses of biodiversity and alterations in ecosystem functions through changes in food webs and food chains. Farmers do not use any organic pesticides; it could be because they are not easily available on the market.

Since the study revealed that some farmers were unable read pesticide labels to determine correct application rates, imply that excessive or lower rates were used by farmers. Common practices revealed were use of arbitrary measures like tablespoons and bottle tops. So, violation of pesticide application procedures was revealed, which results into high or low quantities of pesticides being applied. High pesticide quantities and application frequencies were a response to increased pest and disease problems, as in Okonya et al. (2015). Tomato was the heaviest consumer of pesticides at two routine sprays a week, which most farmers used. Farmers reported, they were not ready to give up the 'insurance' against losses, achieved by pesticide use, imply increased pesticide use in the area, moreover in Uganda, particular pesticides formulations were now within the purchasing power of more producers following the removal of the import tax on agricultural chemicals (Karungi et al., 2011).

About $80 \%$ of farmers apply pesticides to their vegetable fields; weekly or twice a week means that most farmers apply pesticides more frequently and therefore, more pesticides were frequently pumped into the environment. So, effects of such pesticides (pollution, toxicity) were more likely to be exposed to the surrounding biodiversity and could be felt as both short- and long-term effects. Routine pesticide spraying practiced by more than $90 \%$ of the farmers, irrespective of pests and or disease presence, was an indication of incorrect application frequencies of pesticides (twice a week, so on), resulting in unnecessary excess amounts which potentially could increase pesticide residues and pollution in surrounding ecosystems such as water sources.

It was therefore apparent that though spraying pesticides was necessary for increased productivity and quality, aspects of frequency, interval and intensity of pesticides use required desirable knowledge by farmers, since this was likely to cause havoc by accumulating pesticide residues in the different ecosystem components such as water sources, food chains, air among others, hence resulting in ecosystem and biodiversity imbalances. Water and food quality and safety are likely to be affected, and resistance to pesticides by pests and diseases duly likely to exist, if no strategies to regulate frequency, interval and intensity of pesticide application were put in place.

The frequency, intensity and interval of pesticide application keep changing depending on the prevailing weather conditions. During the rainy seasons, different farmers apply pesticide at different intervals ranging from every 3 days, every 4 days, and every 5 days, weekly and above 7 days depending on the type of crop. In dry seasons application intervals ranging from every 4 days, weekly and above 7 days were reported by different farmers. Although both cases had some close intervals of pesticide application, rainy seasons had more pesticides applied to the fields than in the dry seasons. This means, in rainy seasons more pesticides residues accumulate in the ecosystem components such as water sources through run offs and percolation through soil particles, than in dry periods; meaning that more pesticide residues are most likely to be present in water during rainy seasons. 
Given that tomatoes consumed more pesticides, in more close intervals both in wet and dry seasons, followed by onion and cabbages, meant that tomatoes, onions and cabbage contributed more pesticide residues to the ecosystem in the respective order. It was realized that synthetic pesticides were intensively used in vegetable farming (especially on Tomato, Onion and Cabbage). Use of pesticides in vegetable production in this study area of focus was dependent upon high pest infestations, prevalence of diseases, and the crop grown. Therefore the more the farmers apply pesticides more frequently (twice a week, weekly) imply that more pesticides are pumped into the environment, whose likely effects may include high residual accumulation and pollution in the ecosystem and serious biodiversity degradation which can have both short and long term effects to biotic elements.

Other research findings have also shown heavy usage of pesticides on tomato in other countries in Africa; Ntow et al., (2006); Karungi 2011 working on tomato in Ghana indicated that farmers sprayed an average of 6-12 times a season, whereas it was 5-16 times or more per cropping season in Tanzania (Ngowi et al., 2007; Lekei et al., 2014; Karungi 2011. Such heavy use of pesticides implies that pesticide residues accumulation levels in the ecosystem components would raise higher, causing water quality loss, biodiversity imbalances, and frequent contact of farmers with pesticides, could lead to significant health problems.

Fungicides are not easily observed to cause serious and acute damage to farmer's health but it has been reported that there is a long-term risk for cancer development and endocrine disruption resulting from farmer's exposure to fungicides containing mancozeb (Novikova et al., 2003; Mpala et al 2016), which can be by direct physical contact, contact through water and food. The dithiocarbamate family of fungicides is also suspected to have reproductive (Restrepo et al., 1990), and mutagenic effects in human cells exposed to it (Pretty and Waibel, 2012, Pretty, 2012).

Findings also revealed the status quo of biotic constraints to vegetable production in the study area, was high and the easiest available pests and disease control measure was spraying synthetic pesticides. Fungicides were the most used because of fungal blights, especially Phytophthora, which were everpresent, and which would result in more than 75\% crop losses if not checked; this was in line with Akemo et al. (2000) and Karungi et al. (2011). Farmers responded to the threat by effecting routine/calendar sprays with fungicides, majority of them spraying as often as twice a week.

Although pesticides are useful in fostering the agriculture production, but when improperly used can pose dangerous risks to the entire ecosystem. Therefore, knowledge of the possible entry and effects of pesticides contaminants and pollution to the environment requires in-depth analysis of types of pesticides, application methods, and education levels of the users, pesticide handling and the trainings given to the users.

Information concerning farmer's awareness in the use and handling of pesticides

Given that only $27.8 \%$ farmers seek for knowledge on how to apply pesticides, but majority farmers do not, coupled with inadequate trainings in pesticide use; implies that most farmers used pesticides 
incorrectly, which increase risks of resultant excessive or inadequate pesticide quantities and might cause increased residual accumulation and pollution of the ecosystem or resistant strains of pests and diseases due to insufficient doses used. Self-decisions by farmers with less pesticide knowledge, implies incorrect use of pesticides resulting in contamination and pollution of the ecosystem components such as water sources. Farmers' trainings in pesticide use and handling practices were so low compared to the high rate of pesticides use by farmers. However most farmers engaged in vegetable production attained some level of education (Table1), which would implies that, they are able to read instructions on pesticide labels to determine the right application methods, rates of application among others, this is not a guarantee as most farmers did not bother reading instructions while using pesticides.

Bathing and cleansing of spray equipment in water by some farmers; imply a serious risk of reduced water quality due to contamination by pesticides which could build to toxic levels to cause short and or long-term effects. The implication of improper disposal of pesticide containers; for instance, when thrown in water, cause direct water contamination, whereas when thrown to bushes, may still find their way to different ecosystems including water causing contamination and accumulation of pesticide residues in water.

Some farmers were not able to identify expiry dates on pesticide labels, implying that they sometimes applied expired pesticides to their crops, a practice riskier to the crops, the environment and human health. This reflects that majority of farmers did not receive any knowledge from training workshop, seminar or awareness campaigns about pesticide use and handling practices implying high rate of incorrect pesticide usage in the study area, which translates into high accumulation of pesticides residues in the ecosystem, resulting into pollution of the environmental components.

Majority farmers were not able to calibrate their spray equipment to determine right application rates; implying destruction of crops by excessive quantities or pest and or disease resistance to pesticides in case of low quantities which ultimately increases pest populations and continuous crop destruction by resistant disease causing agents. Since use of pesticides for pest management reported as the easiest farmer's option, implied that more pesticides entered surrounding ecosystem components; however, actual amounts of pesticides used in Uganda were not known. In general, a significantly high use of pesticide on vegetables in the study area exists, implying that; increasing the acreage for vegetable growing potentially increases pesticide use in the area, which results in polluting the ecosystem. Farmers apply pesticides to crops sold to the market, improving quality for cash, and as vegetables increasingly become a staple crop in Uganda's economy, farmers apply pesticides to safeguard themselves from yield loss. This high use of pesticides results in contamination of the environment including water resources.

Since most farmers mixed pesticides in their fields which were reportedly on hills, with water sources in adjacent valleys, imply that water run offs during rains, from mixing grounds in the fields could end up in the nearby water sources posing a risk of water contamination by pesticides; but also those who reportedly mixed at the water sources, contaminated the water directly by spills during measurements 
and cleansing of the spray equipment in water sources. This is related to the low number of farmers who received pesticide extension services in respect to the high rate of pesticide use in the area (Table 18), and inadequate agricultural extension officers. It means, majority of the vegetable farmers in the study area apply pesticides with inadequate knowledge, hence improper application and handling practices used and may leads to excessive or inadequate quantities which may increase accumulation of residues in ecosystem components like water and food chains to toxic levels, or cause pest resistance to pesticides which provoke farmers to spray excessively, inputting more pesticide residues to the environment.

Majority of farmers used a lot of pesticides in their fields (Table 10), even when they knew that through runoffs pesticides easily reach water sources. This implies that something forced them to continuously use pesticide, perhaps monetary attachment or profit gains for livelihood. Since more than $80 \%$ of the farmers reported their vegetable gardens being located on the hill sides of the water sources and others had their vegetable fields located in the valleys where water sources were found; and $100 \%$ of them reported that water collecting sources were all located in the valleys, imply a high risk of contaminating water sources by pesticides from vegetable fields through runoffs, percolation through soil particles and spray drifts brought down by rain, hence increasing pesticide residue in water

Farmers used arbitrary tank-mixtures of pesticides as a way to increase effectiveness or save on labour. A similar situation was reported from Tanzania where a study on pesticides usage in small-scale vegetable farms revealed that a third of the interviewed farmers applied pesticides in tank-mixtures (Ngowi et al., 2007; Jokha (2015). In all cases, there were no specific instructions either from the labels or extension workers regarding these tank mixtures. Mixing of pesticides by inexperienced farmers is not encouraged because the combinations used are indiscriminate. The practice defies some of the basic principles of pesticide management. For instance, Metcalfe et al., (2014) in his recommendation of strategies for pesticide management, states that the use of mixtures of pesticides must be avoided, since mixtures of pesticides generally result in the simultaneous development of resistance.

Binhney (2001) working in Ghana attributed the increase in incidences of insect pest infestation of tomato after pesticide applications to indiscriminate combinations of pesticides, particularly of insecticides. Moreover, label instructions do not cover tank mixtures of pesticides and give no information on the compatibility of inert ingredients such as emulsifiers and wetting agents. It is riskier to mix two different types of formulations for example wettable powders with emulsifiable concentrates.

Smit et al., (2002); Karungi et al., (2011), Nansen (2013) and Jokha (2015) observed that there was an interaction between fungicides, insecticides and water mineral content that influenced the efficacy of individual pesticide against fungal pathogens and insect mortality and some tank mixtures induced phytotoxicity on tomato. There is limited information on the reaction and effects of the mixtures being used in the case studies. In addition, farmers did not consider that unspecified tank mixing of pesticides could be less effective and cause adverse effects to their health or the environment. Instead, the tank mixing was carried out to save time, labour cost and with anticipation of high efficacy in pests and 
diseases control. Sherwood et al., (2005) also reported that potato farmers in Ecuador were mixing pesticides mainly to reduce costs associated with spraying.

Findings in this study were also in agreement with findings from the case studies elsewhere in Sub Saharan Africa (Matthews et al., 2003; Ntow et al., 2006; Jokha 2015; Ngowi et al., 2007; Karungi et al., 2011) which show that internationally banned/restricted pesticides such as Carbofuran and Endosulfan are still being used by minimally educated farmers on horticultural crops. These pesticides pose a serious threat to the ecosystem. The problem is particularly widespread in sub-Saharan Africa, where the advent of liberalization of pesticides input markets has weakened quality control (FAO/WHO, 2001; Jokha 2015). Prior to liberalization, there were relatively few actors involved in pesticide provision, which made regulation and control simple.

In Uganda, importation and distribution of pesticides and other agricultural inputs used to be conducted by the Government and its Parastatals, which had proper procedures for safe handling and distribution of pesticides. Entry of more firms into the market runs the risk of erosion of quality control and packaging standards, the breaching of national regulations and the unimpeded movement of banned or restricted chemicals across borders (Mudimu et al., 1995; Jokha 2015). It also raises concerns about the ability of regulatory agencies to control their activities, since it requires more vigorous scrutiny and screening of imports and monitoring of distribution and usage (Mudimu et al., 1995; Williamson, 2003; Jokha 2015) with huge financial and human resource implications for these agencies.

Pesticide provision in a market-driven economy needs an effective regulatory framework in order to create full and fair competition, to protect the environment such as aquatic resources, to guarantee the quality of the products and to avoid the spread of pests and diseases (Shepherd and Farolfi, 1999; Jokha 2015). These are critical challenges for hard-pressed African regulators.

Most of the pesticides on the Ugandan market in particular are pesticides that have been around for a long time within a limited range. On record in 1999, 190 pesticide formulations had been registered (includes insecticide, fungicides, and herbicides), a pittance if compared to developed countries like the United States of America; where over 50,000 had been registered by that period (Schaefers et al., 1999; Jokha 2015). This is a great disadvantage to pesticide users who have limited choice for safe pesticides. This discrepancy in accessibility to safer pesticides between countries at different levels of economic development poses a challenge in developing safer alternatives such as IPM systems in some developing countries. Safer pesticides are either inaccessible or outside the income bracket of small-scale farmers. For such countries to remain competitive in international export markets, the policy environment, particularly regarding registration of newer and safer agrochemicals must be more conducive.

The improper disposal methods of the empty pesticide containers and plastic bags of pesticides imply poor handling. The containers and plastic bags being either thrown in the pit latrines, thrown away in the bush or in water bodies, left around the farms or open burned. This observation correlates with a study in Brazil which assess exposure to pesticides in which most respondents above $50 \%$ reported to leave empty pesticide containers within their fields (Araujo et al., 1999; Jokha 2015). 
Most pesticides have been classified as insecticides, acaricides, molluscides, nematicides, fungicides, rodenticides and herbicides. The common types include organophosphates (Bromophos, DDVP (Dichloro dimethyl vinyl phosphate), Diazinon, Dursban, Dimethoate, Malathion, Parathion), organochlorines (Aldrin, DDT (Dichloro diphenyl trichloroethane), Dieldrin, Lindane, Thiodan, Toxaphene), carbamates (Dithane M45, Dithane M22, Furadan), pyrethrins/pyrethroids (Ambush CY (Permethrin), Ripcord (Cypermethrin, Decamethrin), phenoxy acetic acid (2-4-D (Dichlorophenoxy acetic acid), 2-4-5-T (Trichlorophenoxy acetic acid), MCPA (Monochlorophenoxy acetic acid), inorganic metals (shell copper (copper oxide), lead arsenate arsenic trioxide, phenylmercuric acetate) and bipyridyls (Grammoxone (Paraquat), Weedol and Diquat).

Vegetable farmers use a variety of these pesticides to control a host of pests, ranging from pre-harvest termites to post-harvest storage pests. While many are contact pesticides, systemic pesticides, which are potentially riskier because they penetrate living tissue, are also used.

According to Jeyaratnam (1990) and Zare (2015), 80\% of the Uganda's population are involved in agriculture and a modest estimate of $3 \%$ of all agricultural workers in developing countries are affected by pesticide poisoning each year translating into over 700000 cases in Uganda annually. Safety behaviors in pesticide use are considered the most important determinants of the adverse health effects among farmers, which meant that the risk of pesticide exposure was strongly associated with farmer's behavior when working with pesticides (Sharifzadeh et al., 2019). However, there is limited understanding of farmer's behavior and its determinants especially in developing countries like Uganda. The sampled farmers used different types of insecticides, and fungicides. Some of the farmers applied weedicides for field preparation for vegetables. Both insecticides and fungicides were used by all the farmers since insect and fungal attack was severe.

\section{Conclusion}

The study revealed that proper pesticides handling and application practices were not followed by most farmers in their vegetable fields. The consequence was accumulation of pesticide residues in water, crop produce and the general environment. This was triggered by lack of fundamental skills and knowledge of safe pesticide use, and safety equipment necessary for handling pesticides. The study also adduced that agricultural labourers are causing substantial harm to themselves, their communities and their environment, in their attempt to intensively grow different vegetables. The increasing use of pesticides demands for holistic measures towards preventing further accumulation of residue levels in the ecosystem, lest these become pollutants.

\section{Declarations}

\section{Ethics approval and consent to participate}


Ethics approval was sought from Office of the Dean, Faculty of Agriculture, Uganda Martyrs University. The approval notices also served as an introductory letter for seeking content to individual respondents and participants. The letter is included as supplementary material.

\section{Consent for Publication}

Not applicable

\section{Availability of data and material}

Data will be availed on request.

\section{List of Abbreviations}

IPM - Integrated Pest Management

DDVP - Dichloro dimethyl vinyl phosphate

DDT - Dichloro diphenyl trichloroethane

MCPA - $\quad$ Monochlorophenoxy acetic acid

ACALISE - African Centre of Excellence in Agroecology and Livelihood Systems

\section{Competing interests}

All authors declare that no competing interest exists.

\section{Funding}

We are grateful for the financial support provided by World Bank's African Centre of Excellence in Agroecology and Livelihood Systems (ACALISE) at Faculty of Agriculture, Uganda Martyrs University.

\section{Authors' contributions}

ER: Conducted the study and drafted the manuscript 
GS: Supervised the study, performed statistical analysis and co-drafted manuscript

JB: Designed study tools and co-drafted manuscript

JS: Co-sourced for funding, co-designed study tools and co-drafted manuscript

JM: Conceived the study, sourced for funding and revised the first draft manuscript

\section{Acknowledgements}

We are grateful for the continuous and kind support, guidance and cooperation by the staff of the Faculty of Agriculture, Uganda Martyrs University, offered throughout the struggle, which led to the overall success of this study.

\section{References}

Akemo, M.C., Kyamanywa, S., Luther, G., Ssekyewa, C., Erbaugh, J.M. \& Warren, H. 2000. Developing IPM systems for tomato in Central and Eastern Uganda. IPMCRSP sixth Annual Report. No. 6:117-121.

Amouh, C.N., 2011. A case study of health risk estimate for pesticide-users of fruits and vegetable farmers in Cameroon. Master in Bioscience Engineering, Ghent University, Belgium.

Araujo, A.P., Telles, D.L., Gorni, R. and Lima, L.A. (1999). Endosulpfan residues in Brazilian tomatoes and their impact on public health and the environment. Bulletin of Environmental Contamination and Toxicology, 62:671-676.

Binhney, P.M., 2001. Pesticide use pattern and insecticide residue levels in tomato (Lycopersicum esculentum) in some selected production systems in Ghana. MPhil Thesis, University of Ghana, Legon.

Eyhorn, F., Roner, T. and Specking, H., 2015. Reducing pesticide use and risks-What action is needed? Briefing Paper, Helvetas, pp.14-16

FAO/WHO (2001) Amount of poor-quality pesticides sold in developing countries alarmingly high. FAO/WHO press release, 1 February 2001.

GFC (21 December 2015) “Road distance between Kampala and Kichwamba with map”. Globefeed.com (GFC). Retrieved 21 December 2015.

Google (December 2015) "Location of Uganda technical college Kichwamba at Google maps" (Map). Google Maps. Google. Retrieved 21 December 2015. 
Hicks B (2013) Agricultural pesticides and human health. In: National Association of Geoscience Teachers. Available from: http://serc.carleton.edu/NAGTWorkshops/health/case_studies/pesticides.html. Accessed Jan 13, 2014

Jeyaratnam, J., 1990. Acute pesticide poisoning: a major global health problem. World Health Statatistisc Quarterly, 43(3), pp.139-44.

Jokha, M.O.H.A.M.E.D., 2015. EFFECTS OF Agricultural pesticides and nutrients residue in Weruweru subcatchment, Tanzania. Nairobi: Kenyatta University

Jørs, E., Neupane, D. and London, L., 2018. Pesticide poisonings in low-and middle-income countries.

Karungi, J., S. Kyamanywa, E. Adipala, and M. Erbaugh. 2011. Pesticide utilization, regulation and future prospects in small scale horticultural crop production systems in a developing country, pesticides in the modern world - pesticides use and management, Dr. Margarita Stoytcheva (Ed.), ISBN: 978-953-307-4597, InTech, DOI: 10.5772/17170. Available at: http://www.intechopen.com/books/pesticides-in-the-modernworld-pesticides-use-andmanagement/pesticide-utilisation-regulation-and-future-prospects-in-smallscalehorticultural-crop-production-s [25 June 2014].

Lah K (2011) Effects of pesticides on human health. In: Toxipedia. Available from http://www.toxipedia.org/display/toxipedia/Effects+of+Pesticides+on+Human+Health. Accessed Jan 16, 2014

Mahmood, I., Imadi, S.R., Shazadi, K., Gul, A. and Hakeem, K.R., 2016. Effects of pesticides on environment. In Plant, soil and microbes (pp. 253-269). Springer, Cham.

Matthews, G., Wiles, T., \& Baleguel, P. 2003. A survey of pesticide application in Cameroon. Crop Protection 22: 707-714

Maumbe, B.M. and Swinton, S.M., 2003. Hidden health costs of pesticide use in Zimbabwe's smallholder cotton growers. Social Science \& Medicine, 57(9), pp.1559-1571.

Mengistie, B.T., Mol, A.P., Oosterveer, P. and Simane, B., 2015. Information, motivation and resources: The missing elements in agricultural pesticide policy implementation in Ethiopia. International journal of agricultural sustainability, 13(3), pp.240-256.

Metcalf RL, Changing role of insecticides in crop protection. Annu. Rev. Entomol. 25:119-256 (1980).

Mudimu, G.D., Chigume, S. \& Chikanda, M. 1995. Pesticide use and policies in Zimbabwe. Pesticide Policy Project Publication Series, No. 2. Hanover, Germany: Institut für Gartenbauökonomie, University of Hannover, Germany.

Nansen, C. and Ridsdill-Smith, J.T., 2013. The performance of insecticides-a critical review. In Insecticides-Development of Safer and More Effective Technologies. IntechOpen. 
Ngowi, A.V.F., Mbise, T.J., Ijani, A.S.M., London, L. and Ajayi, O.C., 2007. Pesticides use by smallholder farmers in vegetable production in Northern Tanzania. Crop Protection (Guildford, Surrey), 26(11), p.1617.

Novikova, I.I., Litvinenko, A.I., Boikova, I.V., Yaroshenko, V.A. \& Kalko, G.V. 2003. Biological activity of new microbiological preparations designed for plant protection against diseases of vegetable crops and potato, Mikol. Fitopatol. 37 (1) (2003), pp. 92-98

Ntow, W.J., Gijzen, H.J., Kelderman, P. and Drechsel, P., 2006. Farmer perceptions and pesticide use practices in vegetable production in Ghana. Pest Management Science: formerly Pesticide Science, 62(4), pp.356-365.

Okello, J.J. and Swinton, S.M., 2010. From circle of poison to circle of virtue: pesticides, export standards and Kenya's green bean farmers. Journal of agricultural economics, 61(2), pp.209-224.

Okonya, J.S. and Kroschel, J., 2015. A cross-sectional study of pesticide use and knowledge of smallholder potato farmers in Uganda. BioMed research international, 2015.

Pretty, J. and Waibel, H., 2012. Paying the price: the full cost of pesticides. In The pesticide detox (pp. 6176). Routledge.

Pretty, J. ed., 2012. The pesticide detox: towards a more sustainable agriculture. Earthscan.

Puz-y-Mino, C. Bustamente, G. Sanchez, M.E. \& Leone, P.E. 2002. Cytogenetic monitoring in a population occupationally exposed to pesticides in Ecuador, Environ. Health Perspect. 110:1077-1080.

Schaefers, G.A., Hedlund, R.C. \& Kyamanywa, S. 1999. Report on pesticide use by strategic objective 1 partners and on Uganda's pesticide regulatory status. Task Order No. 1648.

Schaefers, G.A., Hedlund, R.C. \& Kyamanywa, S. 1999. Report on pesticide use by strategic objective 1 partners and on Uganda's pesticide regulatory status. Task Order No. 1648.

Schaefers, G.A., Hedlund, R.C. \& Kyamanywa, S. 1999. Report on pesticide use by strategic objective 1 partners and on Uganda's pesticide regulatory status. Task Order No. 1648.

Sharifzadeh, M.S., Abdollahzadeh, G., Damalas, C.A., Rezaei, R. and Ahmadyousefi, M., 2019. Determinants of pesticide safety behavior among Iranian rice farmers. Science of The Total Environment, 651, pp.2953-2960.

Shepherd, A.W. \& Farolfi, S. 1999. Export crop liberalization in Africa, FAO Agricultural Services Bulletin 135, Rome, 89pp.

Sherwood, S. Cole, D., Crissman, C. \& Paredes, M. 2005. From pesticides to people: improving ecosystem health in the northern Andes. In: J. Pretty, (Ed). The Pesticide Detox. towards a more sustainable agriculture, Earthscan, London, pp. 147-164. 
Smit, Z.K., Indjic, D., Belic, S. \& Miloradov, M., 2002. Effect of water quality on physical properties and biological activity of tank mix insecticide-fungicide spray, In: Paroussi, G., Voyiatzis, D., Paroussis, E. (Eds.), Proceedings of the Second Balkan Symposium on Vegetables and Potatoes (579), International Society Horticultural Science, Leuven, Belgium, pp., 551-556.

Syed Ahmad Ali, 2017. How we can determine the sample size from an unknown population; University of Management and Technology (Pakistan) https://www.researchgate.net/profile/Syed_Ali284

Williamson, S. 2003. Pesticide provision in liberalised Africa: out of control? Agricultural Research and Extension Network. Network Paper No. 126. ISBN 0850036399.

Zare, S., Behzadi, M., Tarzanan, M., Mohamadi, M.B., Omidi, L., Heydarabadi, A.B. and Kazemi, S., 2015. The impacts of pesticides on the health of farmers in Fasa, Iran. Electronic physician, 7(4), p.1168.

\section{Supplementary Files}

This is a list of supplementary files associated with this preprint. Click to download.

- QuestionnaireEziron30May2018.docx 